\title{
Відновлення та корекція рухової активності методом біологічного зворотного зв'язку
}

\author{
Чернишова І. М., Костинська О. М., Луценко О. В, Логвін Г. В. \\ Український науково-дослідний інститут протезування, протезобудування та відновлення \\ працездатності, м. Харків, Україна
}

Актуальність. Можливості фізичної реабілітації пацієнтів з обмеженням фізичних можливостей значно поширилися завдяки застосуванню в комплексній програмі реабілітації методів і технологій, які базуються на принципах зворотного зв’язку (БЗ3).

Мета дослідження: огляд сучасних видів та можливостей систем реабілітації з БЗ3.

Матеріали і методи. Проведення аналізу доступної інформації про сучасні системи Б33.

Результати дослідження та їх обговорення. Механізм дії БЗ3 полягає у безперервному моніторингу в режимі реального часу певних фізіологічних показників і свідоме управління ними за допомогою мультимедійних, ігрових та інших прийомів у заданій області значень, що дозволяє проводити тренування не тільки когнітивних функцій, але й рухових можливостей пацієнта згідно 3 завданням та отриманою інформацією. В результаті здійснюється тренування заданої групи м'язів і формування нового, найбільш оптимального рухового стереотипу. В реабілітації пацієнтів 3 порушенням функції опорно-рухового апарату в якості зворотного зв’язку застосовується електроміографія
(ЕМГ), ультразвукове зображення в режимі реального часу, гоніометрія, відеоспостереження і тензометрія. В реабілітації з застосуванням Б33, крім параметрів ЕМГ, застосовуються також показники електроенцефалографії, частоти дихання і пульсу.

\section{Висновки.}

1. БЗ3 застосовується для відновлення рухової функції скелетних м'язів після перенесеного інсульту, хірургічних втручань, травм, після пошкодження спинного мозку, при дитячому церебральному паралічі (ДЦП), при больовому синдромі й інших нервово-м'язових порушеннях.

2. Б33 може бути застосований як для збільшення активності слабкого або паретичного м'яза, так і для зниження спастичного тонусу.

3. Сучасні системи БЗ3 є багатоканальними і застосовуються для корекції декількох функцій.

4. Перспективи подальших досліджень полягають в оцінці результатів застосування БЗ3 при різній патології.

Ключові слова: Б33, реабілітація, електроміографія.

Конфлікту інтересів немає. 